\title{
FAKTOR-FAKTOR YANG MEMPENGARUHI KINERJA SATUAN POLISI PAMONG PRAJA DAN EFEKTIVITAS ORGANISASI DALAM MEWUJUDKAN KETERTIBAN DAN KETENTRAMAN UMUM KABUPATEN CILACAP
}

\author{
Mukhamar*1, Wiwiek Rabiatul Adawiyah'1, Adi Indrayanto' ${ }^{1}$ \\ ${ }^{1}$ Program Pascasarjana Magister Akuntansi, Fakultas Ekonomi dan Bisnis, Universitas Jenderal Soedirman, \\ Indonesia \\ *Email corresponding: mukhamaramar@gmail.com
}

\begin{abstract}
Abstrak
Tujuan penelitian ini adalah untuk menguji signifikansi pengaruh komunikasi, koordinasi maupun disiplin kerja terhadap kinerja pegawai dan efektivitas organisasi Satuan Polisi Pamong Praja (Satpol PP) Kabupaten Cilacap dalam mewujudkan ketertiban umum dan ketentraman masyarakat. Jenis penelitian yang digunakan adalah penelitian asosiatif. Berdasarkan teknik sampling jenuh (sensus), maka jumlah responden dalam penelitian ini sebanyak 85 pegawai Satpol PP Kabupaten Cilacap. Selanjutnya, teknik analisis data dalam penelitian ini menggunakan analisis regresi berganda. Berdasarkan hasil analisis data, maka dapat diambil kesimpulan bahwa komunikasi, koordinasi maupun disiplin kerja mempunyai pengaruh yang positif dan signifikan terhadap kinerja pegawai. Selanjutnya komunikasi, disiplin kerja maupun kinerja pegawai mempunyai pengaruh yang positif dan signifikan terhadap efektivitas organisasi, sedangkan koordinasi tidak mempunyai pengaruh yang signifikan terhadap efektivitas organisasi Satuan Polisi Pamong Praja (Satpol PP) Kabupaten Cilacap. Mengacu pada kesimpulan tersebut, maka dapat diimplikasikan bahwa sebagai upaya untuk terus meningkatkan kinerja pegawai dan efektivitas organisasi, pihak Satuan Polisi Pamong Praja (Satpol PP) Kabupaten Cilacap perlu memprioritaskan kebijakan yang terkait dengan komunikasi dan disiplin kerja. Cara yang dapat dilakukan diantaranya adalah dengan menerapkan sistem komunikasi kerja yang efektif dalam organisasi berdasarkan atas keterbukaan, empati, dukungan dan kesetaraan. Pihak Satuan Polisi Pamong Praja (Satpol PP) Kabupaten Cilacap juga perlu menerapkan peraturan kerja secara tertulis kepada masing- masing pegawai sesuai dengan bidang tugas yang menjadi tanggung jawabnya, memasang tata tertib mengenai pelaksanaan kerja di kantor maupun tempat kerja pegawai serta terus berupaya meningkatkan kepatuhan dan ketaatan para pegawai terhadap peraturan-peraturan yang berlaku terkait dengan pelaksanaan pekerjaan dengan cara memberikan sanksi secara tegas dan adil terhadap pelanggaran, kesalahan maupun kelalaian kerja yang dilakukan oleh para pegawai.
\end{abstract}

Kata kunci: Komunikasi, Koordinasi Disiplin Kerja, Kinerja Pegawai, Efektivitas Organisasi

\begin{abstract}
The purpose of this study was to examine the significance of the influence of communication, coordination, and work discipline on employee performance and organizational effectiveness of the Civil Service Police Unit (Satpol PP) of Cilacap Regency in realizing public order and public order. The type of research used is associative research. Based on the saturated sampling technique (census), the number of respondents in this study was 85 Satpol PP employees of Cilacap Regency. Furthermore, the data analysis technique in this study uses multiple regression analysis. Based on the results of data analysis, it can be concluded that communication, coordination, and work discipline have a positive and significant impact on employee performance.

Furthermore, communication, work discipline, and employee performance have a positive and significant effect on organizational effectiveness. In contrast, coordination does not significantly affect the organizational effectiveness of the Civil Service Police Unit (Satpol PP) of Cilacap Regency. Referring to this conclusion, it can be implied that as an effort to continue to improve employee performance and organizational effectiveness, the Cilacap District Civil Service Police Unit (Satpol PP) needs to prioritize policies related to communication and work discipline. One way to do this is by implementing an effective work communication system in an organization based on openness, empathy, support, and equality. The Cilacap District Civil Service Police Unit (Satpol PP) also needs to
\end{abstract}


apply written work regulations to each employee following the field of duty that is their responsibility, install rules regarding the implementation of work in the office and employee workplace and continue to strive to improve compliance and obedience of employees to applicable regulations related to the implementation of work by way of giving strict and fair sanctions to violations, mistakes or negligence of work committed by employees.

Keywords: Communication, Work Discipline Coordination, Employee Performance, Organizational Effectiveness

\section{PENDAHULUAN}

Dewasa ini, ketertiban dan ketentraman merupakan salah satu penangkal, pencegah dan penanggulangan segala bentuk pelanggaran hukum dan bentuk-bentuk gangguan lainnya yang dapat meresahkan masyarakat. Sebagai upaya untuk menghadapi dan mengantisipasi perkembangan serta dinamika kehidupan masyarakat seirama dengan tuntutan era globalisasi dan otonomi daerah, maka ketertiban umum dan ketentraman masyarakat menjadi suatu kebutuhan mendasar bagi seluruh lapisan masyarakat. Ketertiban umum dan ketentraman masyarakat merupakan suatu keadaan dinamis yang memungkinkan Pemerintah, Pemerintah Daerah dan masyarakat dapat melakukan kegiatannya dengan tenteram, tertib, dan teratur (PP No. 6 Tahun 2010 Pasal 1 Angka 10).

Undang-Undang Nomor 23 Tahun 2014 tentang Pemerintahan Daerah pada pasal 12 ayat

(1) mengatur mengenai ketenteraman, ketertiban umum, dan pelindungan masyarakat yang merupakan urusan wajib pemerintah daerah, dalam hal ini meliputi pemerintah provinsi, kabupaten dan kota. Sebagai realisasi atas undang-undang tersebut, maka pemerintah daerah meresponnya dengan cara membuat berbagai regulasi atau peraturan untuk mendukung pelaksanaan otonomi di daerahnya. Peraturan yang dibuat oleh pemerintah daerah merupakan salah satu penyangga atas pelaksanaan otonomi daerah. Kewenangan yang dimiliki oleh pemerintah daerah dalam terminologi otonomi tersebut memungkinkan dibuatnya berbagai perangkat berupa aparatur daerah yang berfungsi sebagai pendukung dari pelaksanaan pemerintahan di daerahnya. Salah satu aparatur yang bertugas sebagai pendukung dari pelaksanaan pemerintahan daerah adalah Satuan Polisi Pamong Praja (Satpol PP).

Polisi pamong praja merupakan jabatan fungsional Pegawai Negeri Sipil (PNS) yang penetapannya dilakukan sesuai dengan ketentuan peraturan perundang-undangan. UndangUndang Nomor 23 Tahun 2014 tentang Pemerintahan Daerah dalam Pasal 255 ayat (1) mengatur bahwa Satpol PP dibentuk untuk menegakkan Perda dan Perkada, menyelenggarakan ketertiban umum dan ketenteraman serta menyelenggarakan pelindungan masyarakat. Ketentuan Pasal 256 ayat 71 Undang-Undang Nomor 23 Tahun 2014 mengamanatkan pengaturan tebih lanjut mengenai Satpol PP diatur dalam Peraturan Pemerintah. Peraturan Pemerintah ini mengatur mengenai pembentukan dan organisasi, tugas, fungsi, dan wewenang, sumber daya manusia, kewajiban Pemerintah Daerah, koordinasi, pembinaan, pengawasan, penghargaan, dan pelaporan serta pengaturan kualifikasi PPNS untuk pejabat pimpinan tinggi pratama Satpol PP. Eksistensi dan kontribusi Satuan Polisi Pamong Praja, baik secara personal maupun sebagai organisasi atau kelembagaan sangat diperlukan dalam mendukung suksesnya pelaksanaan otonomi daerah.

Satpol PP sebagai perangkat daerah mempunyai peran yang sangat strategis dalam memperkuat otonomi daerah dan pelayanan publik di daerah. Selain itu, keberadaan Satpol PP 
dalam penyelenggaraan pemerintahan daerah diharapkan dapat membantu adanya kepastian hukum dan memperlancar proses pembangunan di daerah. Untuk menjamin terlaksananya tugas Satpol PP dalam penegakan Perda dan Perkada, penyelenggaraan ketertiban umum dan ketenteraman serta pelindungan masyarakat perlu dilakukan peningkatan, baik dari sisi organisasi atau kelembagaan maupun sumber daya manusia. Terkait dengan hal tersebut, maka pihak pemerintah daerah dituntut untuk mampu mengidentifikasi dan memahami berbagai faktor yang mempengaruhi kinerja pegawai dan efektivitas organisasi Satuan Polisi Pamong Praja.

Tingkat keberhasilan suatu organisasi dapat diukur dengan melihat sejauh mana organisasi mampu mencapai tujuan yang telah ditetapkan. Stoner (1982) menegaskan pentingnya efektivitas organisasi dalam pencapaian tujuan-tujuan organisasi, dan efektivitas adalah kunci dari kesuksesan suatu organisasi (Tangkilisan, 2005). Steers (1977) mengemukakan bahwa dalam penelitian mengenai efektivitas organisasi, sumber daya manusia dan perilaku manusia seharusnya selalu muncul menjadi fokus primer dan usaha- usaha untuk meningkatkan efektivitas seharusnya dimulai dengan meneliti perilaku manusia di tempat kerja. Efektivitas secara empiris berfungsi sebagai variabel penting dalam kegiatan riset dan konsep penting dalam penafsiran fenomena organisasional. Robbins (2010) berpendapat bahwa salah satu faktor penting yang mempengaruhi efektivitas organisai adalah kualitas dan perilaku sumberdaya manusia yang dapat diukur melalui kinerja pegawai.

Kinerja pegawai (employees' job performance) adalah hasil kerja kualitas dan kuantitas yang dicapai oleh seorang pegawai dalam melaksanakan tugasnya sesuai dengan tanggungjawab yang diberikan kepadanya (Mangkunegara, 2009). Kinerja pegawai merupakan hasil kerja yang telah dicapai oleh seorang pegawai dengan standar yang telah ditentukan. Kinerja pegawai yang tinggi merupakan salah satu keunggulan kompetitif suatu organisasi, sebaliknya, rendahnya kinerja pegawai menjadi pemicu kegagalan organisasi dalam mencapai tujuan. Pengukuran kinerja pegawai sebagai wujud dari kualitas dan kuantitas hasil kerja menjadi salah satu aspek penting yang harus diperhatikan oleh setiap organisasi karena sangat bermanfaat sebagai bahan informasi bagi pengambil keputusan dalam merancang kebijakan demi mewujudkan tujuan yang telah ditetapkan oleh organisasi. Mahmudi (2010) mengemukakan bahwa kinerja merupakan suatu konstruk multidimensional yang mencakup banyak faktor yang mempengaruhinya, yaitu faktor personal, faktor kepemimpinan, faktor tim, faktor sistem, dan faktor kontekstual atau situasional. Menurut Kuswadi (2004) beberapa faktor penting yang mempengaruhi kinerja pegawai adalah komunikasi dan koordinasi.

Komunikasi adalah proses penyampaian informasi, gagasan, informasi, pikiran dan ide dari satu orang kepada orang lain (Robbins, 2006). Proses komunikasi memungkinkan anggota organisasi bertukar pikiran dan informasi dengan menggunakan suatu bahasa atau simbol- simbol yang umum digunakan. Komunikasi dapat diibaratkan sebagai darahnya organisasi yang menghubungkan bagian-bagian yang terpisah dalam organisasi. Jadi komunikasi merupakan alat untuk menyatukan kelompok-kelompok kerja yang berbeda dalam suatu organisasi sehingga setiap aktivitas yang dilaksanakan dapat seiring dan sejalan dalam mencapai tujuan organisasi.

Koordinasi juga menjadi faktor penting yang mempengaruhi kinerja pegawai dan efektivitas organisasi Satuan Polisi Pamong Praja karena dalam penyelenggaraan ketertiban umum dan ketenteraman masyarakat, Satpol PP harus berkoordinasi dengan Perangkat Daerah dan/atau instansi terkait lainnya. Koordinasi adalah suatu usaha kerjasama antarbadan, intansi, unit dalam 
pelaksanaan tugas-tugas tertentu sedemikian rupa sehingga terdapat saling mengisi, saling membantu dan saling melengkapi (Hasibuan, 2010). Koordinasi menjadi salah satu unsur keberhasilan organisasi dalam memadukan satu unit kerja organisasi ke dalam unit kerja organisasi lainnya. Setiap unit kerja harus memiliki keterpaduan langkah dan gerak untuk mencapai hasil kerja yang optimal. Ismail (2009) mengemukakan bahwa karateristik pertama dari organisasi adalah adanya upaya koordinasi dari sumber daya manusia yang melibatkan kinerja dalam suatu organisasi. Oleh karena itu, koordinasi akan berpengaruh positif terhadap kinerja pegawai karena penggabungan yang terkoordinasi dengan baik akan mampu meningkatkan kualitas dan kuantitas hasil kerja dari para pegawai dalam melaksanakan tugasnya sesuai dengan tanggung jawab yang diberikan kepadanya.

Penelitian mengenai pengaruh komunikasi dan koordinasi, sebelumnya telah dilakukan oleh Septiani (2018) yang membuktikan bahwa komunikasi dan koordinasi mempunyai pengaruh yang signifikan terhadap kinerja pegawai. Studi yang dilakukan oleh Rukmana et al., (2018) juga menemukan bukti bahwa komunikasi mempunyai pengaruh yang positif dan signifikan terhadap kinerja pegawai. Selanjutnya, penelitian yang dilakukan oleh Sariyanto (2018) dan Darmanto (2018) memberikan bukti bahwa koordinasi mempunyai pengaruh yang positif dan signifikan terhadap kinerja pegawai. Di sisi lain, studi yang dilakukan oleh Fefni (2017) justru menunjukkan hasil sebaliknya bahwa komunikasi organisasi tidak berpengaruh signifikan terhadap kinerja pegawai. Selanjutnya, penelitian yang dilakukan oleh Lovihan (2018) juga menunjukkan hasil bahwa koordinasi tidak berpengaruh signifikan terhadap kinerja pegawai.

Berdasarkan evaluasi dari beberapa penelitian sebelumnya tersebut di atas menunjukan hasil yang bervariasi dan tidak konsisten atau terdapat adanya research gap. Oleh karena itu, maka penelitian ini mencoba untuk melakukan pengujian kembali mengenai pengaruh komunikasi dan koordinasi terhadap kinerja pegawai dengan melakukan pengembangan model melalui penambahan variabel disiplin kerja.

Moekijat (2010) mengemukakan bahwa salah satu faktor penting yang perlu diperhatikan dalam usaha mencapai kinerja pegawai yang tinggi adalah kedisiplinan kerja. Disiplin kerja adalah suatu sikap menghormati, menghargai, patuh, dan taat terhadap peraturan-peraturan yang berlaku, baik yang tertulis maupun tidak tertulis serta sanggup menjalankannya dan tidak mengelak untuk menerima sanksi-sanksinya apabila ia melanggar tugas dan wewenang yang diberikan kepadanya (Sastrohadiwiryo, 2005). Disiplin menjadi faktor yang sangat penting dalam perkembangan karakteristik kepribadian seorang karyawan seperti tanggung jawab, percaya diri, ketekunan dalam bekerja dan kontrol diri serta dapat mengembangkan perilaku yang tepat dalam bekerja.

Organisasi Satuan Polisi Pamong Praja Kabupaten Cilacap dibentuk berdasarkan Peraturan Daerah Kabupaten Cilacap Nomor 9 Tahun 2016 yang di dalamnya mengatur mengenai Organisasi dan Tata Kerja Lembaga Teknis Daerah dan Satuan Polisi Pamong Praja Kabupaten Cilacap. Keberadaan Satpol PP di Kabupaten Cilacap mempunyai peran penting dalam membantu Kepala Daerah (Bupati) untuk menciptakan suatu kondisi daerah yang tentram, tertib dan teratur, sehingga penyelenggaraan roda Pemerintahan dapat berjalan dengan lancar dan masyarakat dapat melakukan kegiatannya dengan aman. Terkait dengan hal tersebut, di samping menegakkan Peraturan Daerah (Perda), Satpol PP juga dituntut untuk mampu menegakkan kebijakan Pemerintah Daerah lainnya, yaitu Peraturan Kepala Daerah (Peraturan Gubernur, Peraturan Bupati/Walikota). Dalam melaksanakan tugasnya, Satuan Polisi Pamong Praja perlu melakukan 
koordinasi dan bekerja sama atau menjalin komunikasi dengan instansi-instansi pemerintah lainnya. Demi melaksanakan tugas dan tanggung jawab tersebut dengan baik, maka para pegawai Satpol PP Kabupaten Cilacap dituntut untuk mampu menunjukkan kinerja terbaik demi meningkatkan efektivitas organisasi dalam mewujudkan ketertiban umum dan ketentraman masyarakat di wilayah Kabupaten Cilacap. Berdasarkan hasil wawancara awal yang telah dilakukan oleh peneliti dengan pihak manajemen dan pegawai Satpol PP Kabupaten Cilacap diperoleh informasi bahwa secara umum pelaksanaan tugas dan pekerjaan dari para pegawai sudah berjalan dengan baik. Namun, pihak manajemen organisasi Satpol PP Kabupaten Cilacap mengakui masih ada beberapa permasalahan terkait dengan tingkat pencapaian kinerja dari sebagian pegawai yang dinilai belum sesuai dengan yang diharapkan. Kondisi demikian ditunjukkan melalui ringkasan Laporan Kinerja Instansi Pemerintahan (LKjIP) Satpol PP Kabupaten Cilacap tahun 2016-2018 seperti terlihat pada Tabel 1.

Tabel 1. Laporan Pencapaian Rata-rata Kinerja Satpol PP Kabupaten Cilacap Tahun 2016- 2018

\begin{tabular}{cccc}
\hline Tahun & $\begin{array}{c}\text { Target } \\
\text { Kinerja }\end{array}$ & Realisasi Kinerja & $\begin{array}{c}\text { Perubahan } \\
(\%)\end{array}$ \\
\hline 2016 & 100 & 85,74 & - \\
2017 & 100 & 86,21 & 0,56 \\
2018 & 100 & 85,63 & $-0,68$ \\
\hline
\end{tabular}

Sumber: LKjIP Satpol PP Kabupaten Cilacap Tahun 2016-2018

Data pada Tabel 1 menunjukkan bahwa nilai realisasi rata-rata kinerja Satpol PP Kabupaten Cilacap selama periode tahun 2016-2018 termasuk dalam kategori baik namun belum sesuai dengan target yang telah ditetapkan (100). Selain itu, data pada Tabel 1 juga menunjukkan bahwa nilai rata-rata pencapaian kinerja Satpol PP Kabupaten Cilacap mengalami penurunan sebesar 0,68 persen pada tahun 2018. Mengacu pada permasalahan tersebut, maka perlu dilakukan beberapa upaya perbaikan agar target kinerja pegawai dan organisasi Satpol PP Kabupaten Cilacap dapat dicapai sesuai dengan yang ditetapkan. Beberapa poin penting yang direkomendasikan dalam Laporan Kinerja Instansi Pemerintahan (LKjIP) Satpol PP Kabupaten Cilacap untuk terus meningkatkan kinerja pegawai dan efektivitas organisasi Satpol PP Kabupaten Cilacap adalah meningkatkan pembinaan disiplin personil dan meningkatkan kekompakan dan keterpaduan dalam bekerja (komunikasi dan koordinasi). Mengacu pada fenomena permasalahan yang terkait dengan kinerja pegawai dan efektivitas organisasi Satpol PP dalam meningkatkan ketertiban umum dan ketentraman masyarakat, maka peneliti tertarik untuk melakukan penelitian dengan judul "Faktor-Faktor yang Mempengaruhi Kinerja Satuan Polisi Pamong Praja dan Efektivitas Organisasi dalam Mewujudkan Ketertiban dan Ketentraman Umum di Wilayah Kabupaten Cilacap"

\section{TINJAUAN PUSTAKA}

\section{Efektivitas Organisasi}

Tingkat keberhasilan suatu organisasi dapat diukur dengan melihat sejauh mana organisasi mampu mencapai tujuan yang telah ditetapkan. Stoner (dalam Tangkilisan, 2005) menegaskan pentingnya efektivitas organisasi dalam pencapaian tujuan-tujuan organisasi, dan efektivitas adalah kunci dari kesuksesan suatu organisasi.

Miller (dalam Tangkilisan, 2005) mengungkapkan bahwa "Effectiveness be define as the degree to which a social system achieve its goals. Effectiveness must be distinguished from efficiency. Efficiency 
is mainly concerned with goal attainments". (Efektivitas adalah seberapa jauh suatu sistem sosial mencapai tujuannya. Efektivitas ini harus dibedakan dengan efisiensi. Efisiensi terutama mengandung pengertian perbandingan antara biaya dan hasil sedangkan efektivitas secara langsung dihubungkan dengan pencapaian suatu tujuan)

didefinisikan sebagai hasil kerja secara kualitas dan kuantitas yang dicapai oleh seorang pegawai dalam melaksanakan tugasnya sesuai dengan tanggung jawab yang diberikan kepadanya (Mangkunegara, 2009). Bernardin dan Russel (dalam Ruky, 2006) menyatakan bahwa "performance is defined as the record of outcomes produced on a specified job function or activity during a specified time period". (Kinerja didefinisikan sebagai catatan tentang hasil-hasil yang diperoleh dari fungsifungsi pekerjaan tertentu atau kegiatan selama kurun waktu tertentu). Menurut Gibson et al., (2012), terdapat 5 (lima) indikator yang dapat digunakan untuk mengukur efektivitas organisasi, yaitu: (1)Productive (produktif). Produktif menggambarkan kemampuan organisasi untuk memproduksi jumlah dan mutu output yang sesuai dengan permintaan lingkungan. (2) Efficiency (efisiensi). Didefinisikan sebagai angka perbandingan (rasio) antara output dan input. (3) Satisfaction (kepuasan). Kepuasan dan semangat kerja adalah istilah yang serupa, yang menunjukkan sampai sejauh organisasi memenuhi kebutuhan para karyawannya. (4) Adaptiveness (adaptasi). Kemampuan adaptasi adalah sampai seberapa jauh organisasi dapat menanggapi perubahan intern dan ekstern. (5) Development (pengembangan). Organisasi harus menginvestasi dalam organisasi itu sendiri untuk memperluas kemampuannya untuk hidup terus (survive) dalam jangka panjang.

\section{Kinerja Pegawai}

Kinerja didefinisikan sebagai hasil kerja secara kualitas dan kuantitas yang dicapai oleh seorang pegawai dalam melaksanakan tugasnya sesuai dengan tanggung jawab yang diberikan kepadanya (Mangkunegara, 2009). Bernardin dan Russel (dalam Ruky, 2006) menyatakan bahwa "performance is defined as the record of outcomes produced on a specified job function or activities during a specified time period". (Kinerja didefinisikan sebagai catatan tentang hasil-hasil yang diperoleh dari fungsi-fungsi pekerjaan tertentu atau kegiatan selama kurun waktu tertentu).

Siagian (2014) menjelaskan bahwa bagi individu, kinerja berperan sebagai umpan balik tentang berbagai hal seperti kemampuan, keletihan, kekurangan dan potensinya yang pada gilirannya bermanfaat untuk menentukan tujuan, jalur, rencana dan pengembangan karirnya. Sedangkan bagi organisasi, kinerja pegawai atau karyawan sangat penting dalam kaitannya dengan pengambilan keputusan tentang berbagai hal seperti identifikasi kebutuhan program pendidikan dan pelatihan, rekruitmen, seleksi, program pengenalan, penempatan, promosi, sistem balas jasa, serta berbagai aspek lain dalam proses manajemen sumber daya manusia. Mangkunegara (2009) mengemukakan bahwa indikator kinerja pegawai adalah sebagai berikut:

Kualitas kerja, Kuantitas kerja, Pelaksanaan tugas, Tanggung jawab

\section{Komunikasi}

Komunikasi adalah proses penyampaian informasi, gagasan, pikiran dan ide dari satu orang kepada orang lain (Robbins, 2006). Menurut Zainal, dkk., (2015) komunikasi adalah hubungan lisan maupun tulisan antara dua orang atau lebih yang dapat menimbulkan pemahaman dalam suatu masalah. Proses komunikasi memungkinkan anggota organisasi bertukar pikiran dan informasi dengan menggunakan suatu bahasa atau simbol-simbol yang umum digunakan. Gitosudarmo dan 
Sudita (dalam Pangewa, 2004), menegaskan bahwa komunikasi ibaratnya darahnya organisasi yang menghubungkan bagian-bagian yang terpisah dalam organisasi. Jadi komunikasi merupakan alat untuk menyatukan kelompok-kelompok kerja yang berbeda dalam suatu organisasi sehingga setiap aktivitas yang dilaksanakan dapat seiring dan sejalan dalam mencapai tujuan organisasi.

Goldhaber (2009) mengemukakan bahwa: "Organizational communication is the process of creating and exchanging messages within a network of interdependent relationship to cope with environmental encertainly". (Komunikasi organisasi adalah proses menciptakan dan saling tergantung satu sama lain untuk mengatasi lingkungan yang selalu berubah-ubah). Dengan demikian komunikasi organisasi terdiri dari komunikasi internal dan eksternal, dimana komunikasi internal merupakan komunikasi yang berlangsung di antara anggota di dalam organisasi, baik pimpinan kepada bawahan, bawahan kepada bawahan dan sebagainya, sedangkan komunikasi eksternal adalah komunikasi yang berlangsung dengan pihak luar organisasi. Menurut Umar (2012), komunikasi yang terjadi dalam organisasi dapat diukur menggunakan empat indikator berikut: Keterbukaan. Empati, Dukungan, Kesamaan/Kesetaraan

\section{Koordinasi}

Koordinasi adalah suatu usaha kerjasama antar badan, intansi, unit dalam pelaksanaan tugas-tugas tertentu sedemikian rupa, sehingga terdapat saling mengisi saling membantu dan saling melengkapi (Hasibuan, 2010). Menurut Handoko (2001), koordinasi adalah proses pengintegrasian tujuan dan kegiatan pada satuan yang terpisah pada suatu organisasi untuk mencapai tujuan secara efesien dan efektif.

Manullang (2010) mendefinisikan koordinasi sebagai usaha mengarahkan kegiatan seluruh unit-unit organisasi agar tertuju untuk memberikan sumbangan semaksimal mungkin demi mencapai tujuan organisasi secara keseluruhan. Dengan adanya koordinasi akan terdapat keselarasan aktivitas di antara unit-unit organisasi dalam mencapai tujuan organisasi. G.R. Terry (dalam Hasibuan, 2010) menyatakan bahwa "Coordination is the erdely synchronization of effort to provide the proper amount, timing and directing of execution resulting in harmonious and unified actions to a stated objective". (Koordinasi adalah suatu usaha yang sinkron dan teratur untuk menyediakan jumlah dan waktu yang tepat, dan mengarahkan pelaksanaan untuk menghasilkan suatu tindakan yang seragam dan harmonis pada sasaran yang telah ditentukan). Koordinasi dapat diukur menggunakan dua indikator berikut (Hasibuan 2010): 1) Koordinasi vertikal (vertical coordination) adalah kegiatan-kegiatan penyatuan, pengarahan yang dilakukan oleh atasan terhadap kegiatan unit-unit kesatuan-kesatuan kerja yang ada di bawah wewenang dan tanggung jawabnya. Koordinasi vertikal ini secara relalatif mudah dilakukan, karena atasan dapat memberikan sanksi kepada aparat yang sulit diatur, 2) Koordinasi horizontal (horizontal coordination) adalah mengkoordinasikan tindakan- tindakan atau kegiatankegiatan penyatuan, pengarahan yang dilakukan terhadap kegiatan- kegiatan penyatuan, pengarahan yang dilakukan terhadap kegiatan-kegiatan dalam tingkat organisasi (aparat) yang setingkat.

\section{Disiplin Kerja}

Disiplin kerja adalah suatu sikap menghormati, menghargai, patuh, dan taat terhadap peraturan-peraturan yang berlaku, baik yang tertulis maupun tidak tertulis serta sanggup 
menjalankannya dan tidak mengelak untuk menerima sanksi-sanksinya apabila ia melanggar tugas dan wewenang yang diberikan kepadanya (Sastrohadiwiryo, 2005). Definisi tersebut memberikan penegasan bahwa disiplin merupakan faktor yang sangat penting dalam perkembangan karakteristik kepribadian seorang karyawan seperti tanggung jawab, percaya diri, ketekunan dalam bekerja dan kontrol diri serta dapat mempertahankan dan mengembangkan perilaku yang tepat dalam bekerja.

Davis (dalam Mangkunegara dan Waris, 2015) mengemukakan bahwa "Discipline is management action to enforce organization standars, or work discipline can be defines as implementation management guidelines to strengthen the organization". (Disiplin adalah tindakan manajemen untuk menegakkan standar-standar organisasi, atau disiplin kerja dapat didefinisikan sebagai pedoman manajemen dalam mengimplementasikan standar kerja demi memperkuat organisasi). Menurut Simamora (2010), disiplin kerja adalah suatu prosedur yang mengoreksi atau menghukum bawahan karena melanggar peraturan. Hasibuan (2010) memberikan pengertian disiplin kerja sebagai kesadaran dan kesediaan seseorang untuk mentaati semua peraturan perusahaan dan norma-norma sosial yang berlaku. Sedangkan menurut Zainal, dkk., (2015), disiplin kerja adalah suatu alat yang digunakan para manajer untuk berkomunikasi dengan karyawan agar mereka bersedia untuk mengubah suatu perilaku serta sebagai suatu upaya untuk meningkatkan kesadaran dan kesediaan seseorang untuk mentaati semua peraturan perusahaan dan normanorma sosial yang berlaku. Menurut Sastrohadiwiryo (2005), disiplin kerja karyawan dapat diukur menggunakan beberapa indikator berikut:

Frekuensi kehadiran karyawan pada hari-hari kerja, Masuk dan pulang kerja tepat waktu, Ketaatan karyawan terhadap prosedur/standar kerja, Ketaatan karyawan terhadap peraturan perusahaan

\section{PENGEMBANGAN HIPOTESIS}

\section{Pengaruh Komunikasi Terhadap Kinerja Pegawai}

Menurut Kuswadi (2004), kinerja pegawai dipengaruhi oleh komunikasi. Komunikasi yang efektif di dalam organisasi akan dapat meningkatkan saling pengertian antar sesama rekan kerja dan juga dengan atasan, sedangkan komunikasi yang tidak efektif akan berdampak buruk bagi kehidupan organisasi, seperti konflik antar karyawan. Robbins (2006) mengemukakan bahwa komunikasi yang buruk merupakan sumber konflik antarpribadi yang akan menurunkan kinerja individu pegawai.

Studi sebelumnya yang dilakukan oleh Ishtiaque dan Habib (2016) dengan judul "Impact of Internal Communication in Organizational Development" mengungkapkan bahwa komunikasi memainkan peran kooperatif dalam menghubungkan dan mengoordinasikan kegiatan melalui pengelolaan sumber daya inti dan manusia secara lebih baik, dimana komunikasi terbukti mampu mengoptimalkan produktivitas dan kinerja karyawan. Penelitian yang dilakukan oleh Marta dan Triwijayanti (2016) membuktikan bahwa komunikasi organisasi berpengaruh positif dan signifikan terhadap kinerja karyawan. Selanjutnya, penelitian yang dilakukan oleh Rukmana et al., (2018) juga menemukan bukti bahwa komunikasi (communication) mempunyai pengaruh yang positif dan signifikan terhadap kinerja pegawai (employee performance). Mengacu pada penjelasan tersebut, maka hipotesis pertama dapat dirumuskan sebagai berikut:

$\mathrm{H}_{1}$ : Komunikasi mempunyai pengaruh yang positif dan signifikan terhadap kinerja 


\section{pegawai.}

\section{Pengaruh Koordinasi Terhadap Kinerja Pegawai}

Koordinasi menjadi salah satu unsur keberhasilan organisasi dalam memadukan satu unit kerja organisasi ke dalam unit kerja organisasi lainnya. Setiap unit kerja harus memiliki keterpaduan langkah dan gerak untuk mencapai hasil kerja yang optimal. Secara teoritis, karateristik pertama dari organisasi adalah adanya koordinasi upaya dari sumber daya manusia yang melibatkan kinerja dalam suatu organisasi (Solihin, 2009). Oleh karena itu, koordinasi akan berpengaruh positif terhadap kinerja pegawai karena penggabungan yang terkoordinasi dengan baik akan mampu meningkatkan kualitas dan kuantitas hasil kerja dari para pegawai dalam melaksanakan tugasnya sesuai dengan tanggung jawab yang diberikan kepadanya.

Penelitian sebelumnya yang dilakukan oleh Octorano (2015) membuktikan bahwa koordinasi berpengaruh positif signifikan terhadap kinerja pegawai. Studi yang dilakukan oleh Fleury et al., (2017) dengan judul "Variables Associated with Work Performance in Multidisciplinary Mental Health Teams" menyimpulkan bahwa salah satu faktor penting yang mempengaruhi kinerja pegawai adalah koordinasi kerja (work coordination). Selanjutnya, studi yang dilakukan oleh Sariyanto (2018) dan Darmanto (2018) juga menemukan bukti bahwa koordinasi mempunyai pengaruh yang positif dan signifikan terhadap kinerja pegawai. Berdasarkan uraian tersebut, maka hipotesis kedua dalam penelitian ini dapat dirumuskan sebagai berikut:

\section{$\mathrm{H}_{2}$ : Koordinasi mempunyai pengaruh yang positif dan signifikan terhadap kinerja pegawai.}

\section{Pengaruh Disiplin Kerja Terhadap Kinerja Pegawai}

Disiplin kerja merupakan faktor penting yang harus diperhatikan oleh pihak manajemen organisasi dalam mencapai tingkat kuantitas dan kualitas hasil kerja yang terbaik dari para pegawainya. Terry (dalam Suzanto dan Fitriasari, 2014) mengemukakan bahwa disiplin kerja merupakan alat penggerak karyawan agar setiap pekerjaan dapat dilakukan dengan baik sesuai dengan aturan kerja dan standar yang telah ditetapkan oleh pihak manajemen. Oleh karena itu, semakin baik tingkat kedisiplinan pegawai dalam bekerja, maka akan semakin baik pula kualitas dan kuantitas hasil kerja yang dapat dicapai oleh para pegawai.

Studi yang dilakukan oleh Mangkunegara dan Waris (2015) dengan judul "Effect of Training, Competence and Discipline on Employee Performance in Company" menunjukkan hasil bahwa disiplin kerja berpengaruh positif dan signifikan terhadap kinerja karyawan. Penelitian yang dilakukan oleh Vionita, dkk., (2017) membuktikan bahwa disiplin kerja berpengaruh positif terhadap kinerja pegawai. Selanjutnya, studi yang dilakukan oleh Hardiansyah (2017) juga menemukan bukti bahwa disiplin kerja mempunyai pengaruh yang positif terhadap kinerja pegawai. Berdasarkan uraian tersebut, maka hipotesis ketiga dalam penelitian ini dapat dirumuskan sebagai berikut:

$\mathrm{H}_{3}$ : Disiplin kerja mempunyai pengaruh yang positif dan signifikan terhadap kinerja pegawai.

\section{Pengaruh Komunikasi Terhadap Efektivitas Organisasi}

Kuswadi (2004) mengemukakan bahwa komunikasi merupakan unsur penting dalam kehidupan organisasi. Eksistensi suatu organisasi sangat ditentukan oleh kemampuan sumber daya manusia dalam berkomunikasi demi mencapai tujuan organisasi. Komunikasi dalam sistem pengendalian manajemen merupakan alat untuk mengarahkan, memotivasi, memonitor dan mengevaluasi 
pelaksanaan manajemen dalam proses pencapaian tujuan organisasi. Menurut Muhammad (2011), dengan adanya komunikasi yang efektif, maka suatu organisasi dapat berjalan dengan baik dan berhasil dalam mencapai tujuannya.

Hasil penelitian yang dilakukan oleh Widyastuti (2017) menunjukkan bukti bahwa komunikasi berpengaruh positif signifikan terhadap efektivitas organisasi. Studi yang dilakukan oleh Shonubi dan Akintaro (2016) dengan judul "The Impact of Effective Communication on Organizational Performance" menyimpulkan bahwa komunikasi berpengaruh terhadap tingkat efektivitas dan efisiensi kinerja organisasi. Selanjutnya, studi yang dilakukan oleh Ferdiansyah (2018) juga menemukan bukti bahwa komunikasi mempunyai pengaruh yang positif dan signifikan terhadap efektivitas organisasi. Berdasarkan uraian tersebut, maka hipotesis keempat dapat dirumuskan sebagai berikut:

\section{$\mathrm{H}_{4}$ : Komunikasi mempunyai pengaruh yang positif dan signifikan terhadap efektivitas organisasi.}

\section{Pengaruh Koordinasi Terhadap Efektivitas Organisasi}

Menurut Soetopo (2012), keefektifan organisasi merupakan ketepatan sasaran suatu proses yang terjadi pada lembaga formal yang menyelenggarakan suatu kerjasama dengan komponenkomponen yang saling dikoordinasikan untuk mencapai tujuan. Suganda (dalam Nazarudin, 2016) menyatakan bahwa koordinasi memegang peranan penting dalam meningkatkan efektivitas yaitu melalui kesempatan yang diberikan oleh pimpinan kepada para pegawai untuk mengembangkan dan meningkatkan kemampuan serta keterampilan bagi terciptanya efektivitas dalam organisasi.

Studi sebelumnya yang dilakukan oleh Osifo (2013) dengan judul "The Effects of Coordination on Organizational Performance: An Intra and Inter Perspective" menunjukkan hasil bahwa koordinasi mampu meningkatkan efektivitas kinerja organisasi yang lebih baik melalui ikatan internal dan eksternal yang memberikan keunggulan bagi suatu organisasi. Penelitian yang dilakukan oleh Enadarlita dan Asvio (2019) menemukan bukti bahwa koordinasi mempunyai pengaruh yang positif dan signifikan terhadap efektivitas organisasi. Selanjutnya, hasil studi sebelumnya yang dilakukan oleh Nazarudin (2016) juga membuktikan bahwa koordinasi mempunyai pengaruh yang positif dan signifikan terhadap efektivitas organisasi. Berdasarkan uraian tersebut, hipotesis kelima dapat dirumuskan sebagai berikut:

\section{$\mathrm{H}_{5}$ : Koordinasi mempunyai pengaruh yang positif dan signifikan terhadap efektivitas organisasi.}

\section{Pengaruh Disiplin Kerja Terhadap Efektivitas Organisasi}

Organisasi dibentuk oleh individu dan kelompok individu yang bekerja secara kolaboratif dan saling tergantung untuk memastikan bahwa tujuan atau target organisasi dapat dicapai secara efektif. Menurut Idris dan Alegbeleye (2015), individu dan kelompok individu dalam organisasi yang memiliki minat, ambisi, orientasi dan fokus berbeda kemungkinan besar akan dapat menimbulkan konflik kepentingan di antara individu maupun kelompok individu sehingga akan memicu sikap dan perilaku menyimpang dari peraturan organisasi yang telah ditetapkan. Salah satu cara untuk memastikan ketertiban dan kepatuhan terhadap aturan yang ditetapkan organisasi di tempat kerja adalah disiplin kerja. Dengan demikian, maka disiplin kerja dari masing-masing individu pegawai menjadi salah satu faktor penentu dalam mencapai efektivitas organisasi.

Studi yang dilakukan oleh Idris dan Alegbeleye (2015) dengan judul "Discipline and 
Organization Effectiveness: A Study of Nigeria Customs Service" menunjukkan bahwa terdapat hubungan yang positif dan signifikan antara disiplin kerja dengan efektivitas organisasi. Penelitian sebelumnya yang dilakukan oleh Purnomo (2006) mengungkapkan bahwa rendahnya disiplin kerja pegawai dalam organisasi menyebabkan efektivitas organisasi sulit tercapai. Selanjutnya, studi yang dilakukan oleh Nduka et al., (2019) juga menemukan bukti bahwa disiplin kerja (workplace discipline) mempunyai hubungan yang positif signifikan dengan efektivitas organisasi (organizational effectiveness). Berdasarkan uraian tersebut, maka hipotesis keenam dapat dirumuskan sebagai berikut:

\section{H$_{6}$ : Disiplin kerja mempunyai pengaruh yang positif dan signifikan terhadap efektivitas organisasi.}

\section{Pengaruh Kinerja Pegawai Terhadap Efektivitas Organisasi}

Kinerja individu pegawai merupakan salah satu faktor penting yang mempengaruhi efektivitas pencapaian tujuan organisasi karena organisasi pada dasarnya dijalankan oleh manusia. Jassim dan Jaber (2007) berpendapat bahwa penilaian kinerja pegawai memiliki peran penting untuk mengevaluasi perilaku mereka dalam mencapai tujuan organisasi. Tujuan pokok penilaian kinerja adalah untuk memandu dan mengarahkan sikap dan perilaku kerja pegawai dalam mencapai sasaran organisasi dan dalam mematuhi standar perilaku yang telah ditetapkan sebelumnya agar membuahkan tindakan dan hasil yang diinginkan. Menurut Gibson et al., (2012), efektivitas organisasi mana pun sangat dipengaruhi oleh perilaku manusia, dimana penetapan tujuan merupakan cara yang efektif untuk meningkatkan kinerja pegawai. Oleh karena itu, maka semakin baik hasil kerja secara kualitas dan kuantitas yang mampu dicapai oleh para pegawai akan dapat meningkatkan efektivitas organisasi.

Studi yang dilakukan oleh Tahsildari dan Shahnaei (2015) dengan judul "Enhancing Organizational Effectiveness by Performance Appraisal, Training, Employee Participation, and Job Definition" menemukan bukti bahwa penilaian kinerja pegawai berpengaruh positif dan signifikan terhadap efektivitas organisasi. Studi yang dilakukan oleh Fernanda (2015) memberikan bukti bahwa kinerja pegawai mempunyai pengaruh yang positif dan signifikan terhadap efektivitas organisasi. Penelitian sebelumnya yang dilakukan oleh Zulkarnain (2012) juga membuktikan bahwa kinerja pegawai mempunyai pengaruh yang positif dan signifikan terhadap efektivitas organisasi. Mengacu pada uraian tersebut, maka hipotesis ketujuh dalam penelitian ini dapat dirumuskan sebagai berikut:

\section{$\mathrm{H}_{7}$ : Kinerja pegawai mempunyai pengaruh yang positif dan signifikan terhadap efektivitas organisasi.}

\section{METODE PENELITIAN}

Jenis penelitian yang digunakan adalah penelitian asosiatif. Penelitian ini dilakukan di Kantor Satuan Polisi Pamong Praja (Satpol PP) Kabupaten Cilacap yang beralamat di Jl. Kelud No.15, Cilacap, Sidanegara, Kec. Cilacap Tengah, Kabupaten Cilacap, Jawa Tengah 53212. Penelitian ini dilaksanakan pada bulan Januari tahun 2020. Objek penelitian ini adalah kinerja pegawai dan efektivitas organisasi serta faktor-faktor yang mempengaruhinya, yaitu komunikasi, koordinasi dan disiplin kerja. Populasi dalam penelitian ini adalah keseluruhan jumlah pegawai Satuan Polisi Pamong Praja (Satpol PP) Kabupaten Cilacap yaitu sebanyak 85 orang. Pengambilan sampel dalam penelitian ini dilakukan 
menggunakan teknik sampling jenuh (sensus) yaitu suatu teknik penentuan sampel jika semua anggota populasi digunakan sebagai sampel (Siyoto dan Sodik, 2015). Mengacu pada teknik sampling tersebut, maka jumlah responden dalam penelitian ini sebanyak 85 pegawai Satpol PP Kabupaten Cilacap.

Penelitian ini menggunakan data primer yaitu data yang dikumpulkan sendiri oleh peneliti langsung dari sumber pertama (Suliyanto, 2006). Jenis data penelitian ini berupa jawaban kuesioner dari para responden mengenai persepsi mereka terhadap variabel komunikasi, koordinasi, disiplin kerja, kinerja pegawai dan efektivitas organisasi. Kuisioner, yaitu dengan cara menyusun daftar pertanyaan yang ditujukan kepada responden mengenai variabel-variabel yang diteliti.

\section{TEKNIK ANALISIS DATA}

\section{Skala Pengukuran Variabel Penelitian}

Variabel-variabel dalam penelitian ini diukur menggunakan skala Likert, dimana untuk setiap pertanyaan atau pernyataan dibuka peluang kemungkinan lima alternatif jawaban. Responden diharapkan memilih salah satu jawaban yang dianggap paling sesuai dengan persepsi atau penilaian mereka terkait dengan kondisi yang dihadapi. Kriteria penentuan skor untuk masing- masing jawaban adalah sebagai berikut (Suliyanto, 2011):

$\begin{array}{ll}\text { Sangat Setuju (SS) } & \text { skor } 5 \\ \text { Setuju (S) } & \text { skor 4 } \\ \text { Netral (N) } & \text { skor } 3 \\ \text { Tidak Setuju TS) } & \text { skor 2 } \\ \text { Sangat Tidak Setuju (STS) } & \text { skor } 1\end{array}$

\section{Uji Validitas Kuesioner}

Validitas didefinisikan sebagai sejauh mana ketepatan dan kecermatan suatu alat ukur dalam melakukan fungsi ukurnya (Suliyanto, 2011). Uji validitas dalam penelitian ini dilakukan menggunakan teknik korelasi product moment dengan rumus sebagai berikut (Umar, 2002):

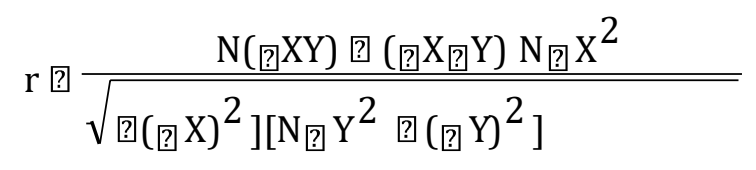

\section{Uji Reliabilitas Kuesioner}

Reliabilitas pada dasarnya adalah sejauh mana hasil suatu pengukuran dapat dipercaya. Jika hasil pengukuran yang dilakukan berulang menghasilkan nilai atau hasil yang relatif sama, maka pengukuran tersebut dianggap memiliki tingkat reliabilitas yang baik (Suliyanto, 2011). Reliabilitas kuesioner dalam penelitian ini diukur menggunakan teknik Cronbanch Alpha dengan rumus sebagai

$$
r=\left[\frac{k}{k-1}\right]\left[1-\frac{\sum \sigma_{b}^{2}}{\sigma_{t}^{2}}\right]
$$

berikut (Umar, 2002):

Jika cronbanch alpha $>$ cut of value (0.60), berarti kuesioner reliabel

Jika cronbanch alpha $\leq$ cut of value $(0.60)$, berarti kuesioner tidak reliabel

\section{Uji Asumsi Klasik}

Uji Normalitas 
Uji normalitas dimaksudkan untuk menguji apakah nilai residual yang telah distandarisasi pada model regresi berdistribusi normal atau tidak. Uji normalitas dalam penelitian ini menggunakan uji statistik non-parametrik Kolmogorov-Smirnov. Nilai residual terstandarisasi berdistribusi normal jika KS hitung < KS tabel atau nilai sig. > alpha (Suliyanto, 2011).

\section{Uji Multikolinieritas}

Uji multikolinearitas bertujuan untuk menguji apakah dalam model regresi ditemukan adanya korelasi yang tinggi atau sempurna antar variabel independen. Jika dalam model regresi yang terbentuk terdapat korelasi yang tinggi atau sempurna di antara variabel bebas maka model regresi tersebut dinyatakan mengandung gejala multikolinier. Untuk mendeteksi ada tidaknya gejala multikolinieritas adalah dengan melihat nilai variance inflation factor (VIF) dari masingmasing variabel bebas terhadap variabel terikatnya. Jika nilai VIF tidak lebih dari 10, maka model dinyatakan tidak terdapat gejala multikolinier (Suliyanto, 2011).

\section{Uji Heteroskedastisitas}

Heteroskedastisitas berarti ada varian variabel pada model regresi yang tidak sama (konstan). Uji heteroskedastisitas dalam penelitian ini menggunakan metode park gleyser. Dengan menggunakann metode ini, gejala heteroskedastisitas akan ditunjukkan oleh koefisien regresi dari masing-masing variabel independen terhadap nilai absolut residunya (e), jika nilai probabilitasnya > nilai alpha-nya $(0,05)$, maka dapat dipastikan bahwa model tidak mengandung unsur heteroskedastisitas atau nilai $t_{\text {hitung }} \leq t_{\text {tabel }}$ pada tingkat keyakinan $95 \%$ atau alpha 0,05 (Suliyanto, 2011).

\section{Analisis Regresi Linear Berganda}

Proses analisis data dilakukan berdasarkan hasil tabulasi jawaban responden dari kuesioner yang telah didistribusikan dengan memberikan dan menjumlahkan bobot jawaban pada masing-masing pertanyaan untuk masing-masing variabel. Selanjutnya, pengujian signifikansi pengaruh variabel komunikasi (X1), koordinasi (X2), dan disiplin kerja (X3) terhadap kinerja pegawai (Y1) dilakukan menggunakan teknik analisis regresi linear berganda dengan persamaan regresi model pertama sebagai berikut (Suliyanto, 2011):

$$
\mathrm{Y}_{1}=\mathrm{a}+\mathrm{b}_{1} \mathrm{X}_{1}+\mathrm{b}_{2} \mathrm{X}_{2}+\mathrm{b}_{3} \mathrm{X}_{3}+\mathrm{e}
$$

Keterangan:

$$
\mathrm{Y}_{1}=\text { Kinerja pegawai } \mathrm{b}_{\mathrm{i}}=
$$

Koefisien regresi $\mathrm{X}_{1}=$

Komunikasi

$\mathrm{X}_{2}=$ Koordinasi $\mathrm{X}_{3}$

$=$ Disiplin kerja $\mathrm{e}$ = error

Selanjutnya pengujian signifikansi pengaruh variabel komunikasi (X1), koordinasi (X2) disiplin kerja (X3) dan kinerja pegawai (Y1) terhadap efektivitas organisasi $\left(\mathrm{Y}_{2}\right)$ dilakukan menggunakan teknik analisis regresi linear berganda dengan persamaan regresi model kedua sebagai berikut (Suliyanto, 2011):

$$
\mathrm{Y}_{2}=\mathrm{a}+\mathrm{b}_{1} \mathrm{X}_{1}+\mathrm{b}_{2} \mathrm{X}_{2}+\mathrm{b}_{3} \mathrm{X}_{3}+\mathrm{b}_{4} \mathrm{Y}_{1}+\mathrm{e}
$$

Keterangan:

$\mathrm{Y}_{2}=$ Efektivitas organisasi $\mathrm{b}_{\mathrm{i}}$ 
$=$ Koefisien regresi

$\mathrm{X}_{1}=$ Komunikasi $\mathrm{X}_{2}$

$=$ Koordinasi $\mathrm{X}_{3}=$

Disiplinkerja

$\mathrm{Y}_{1}=$ Kinerja pegawai $\mathrm{e}$

$=$ error

Pembentukan model regresi dilanjutkan dengan pengujian kelayakan model berdasarkan nilai koefisien determinasi $\left(\mathrm{R}^{2}\right)$ dan uji F sebagai berikut (Gani dan Amalia, 2015):

\section{Koefisien Determinasi $\left(\mathbf{R}^{2}\right)$}

Koefisien determinasi pada intinya mengukur seberapa jauh kemampuan model dalam menerangkan variabel dependen. Nilai $\mathrm{R}^{2}$ yang kecil berarti kemampuan variabel independen (yaitu disiplin kerja, etos kerja, loyalitas karyawan dan semangat kerja) dalam menjelaskan variabel dependen (yaitu kinerja karyawan) relatif terbatas. Nilai yang mendekati satu berarti variabel bebas (independen) memberikan hampir semua informasi yang dibutuhkan untuk memprediksi variasi perubahan variabel terikat (dependen). Koefisien determinasi mempunyai kelemahan terhadap jumlah variabel bebas yang dimasukkan ke dalam model regresi, dimana setiap penambahan satu variabel bebas dan jumlah pengamatan dalam model akan meningkatkan nilai $\mathrm{R}^{2}$ meskipun variabel yang dimasukan tersebut tidak memiliki pengaruh yang signifikan terhadap variabel tergantungnya. Oleh karena itu, banyak peneliti menganjurkan untuk menggunakan koefisien determinasi yang telah disesuaikan (adjusted $R^{2}$ ) pada saat mengevaluasi mana model regresi terbaik (Suliyanto, 2011).

Koefisien determinasi yang telah disesuaikan berarti bahwa koefisien tersebut telah dikoreksi dengan memasukkan jumlah variabel dan ukuran sampel yang digunakan. Rumus untuk menghitung koefisien determinasi yang disesuaikan adalah sebagai berikut (Suliyanto, 2011):

$$
R^{2} \text { adj }=R^{2}-\frac{P\left(1-R^{2}\right)}{N-P-1}
$$

Keterangan:

$R^{2}$ adj = Koefisien determinasi yang telah disesuaikan

$R^{2} \quad=$ Koefisien determinasi

$N \quad=$ Ukuran sampel

$\mathrm{P} \quad=$ Jumlah variabel bebas

\section{Uji F}

Uji F atau goodness of fit test adalah pengujian kelayakan model (Gani dan Amalia, 2015). Model yang layak adalah model yang dapat digunakan untuk mengestimasi populasi. Model regresi dikatakan layak jika nilai $\mathrm{F}$ sebuah model memenuhi kriteria yang telah ditetapkan. Bilangan $\mathrm{F}$ dapat dicari dengan menggunakan rumus berikut (Gani dan Amalia, 2015):

$$
\mathrm{F} \text { ? } \frac{\mathrm{R}^{2} /(\mathrm{k}-1)}{1 \mathrm{~g} \mathrm{R}^{2} /(\mathrm{n}-\mathrm{k})}
$$

Keterangan:

$\mathrm{F} \quad=$ Nilai $\mathrm{F}_{\text {hitung }}$ 


$$
\begin{aligned}
\mathrm{R}^{2} & =\text { Koefisien determinasi } \mathrm{k} \\
& =\text { Jumlah variabel } \\
\mathrm{n} & =\text { Ukuran sampel }
\end{aligned}
$$

Ho diterima dan Ha ditolak jika nilai $\mathrm{F}_{\text {hitung }}$ ? $\mathrm{F}_{\text {tabel, }}$, sehingga model regresi dinyatakan tidak layak digunakan untuk mengestimasi populasi atau tidak memenuhi goodness of fit.

Ho ditolak dan Ha diterima jika nilai $\mathrm{F}_{\text {hitung }}>\mathrm{F}_{\text {tabel, }}$ sehingga model regresi dinyatakan layak digunakan untuk mengestimasi populasi atau memenuhi goodness of fit.

Pengujian Hipotesis dengan Uji t

Pengujian hipotesis pada model regresi digunakan untuk mengetahui pengaruh nyata (signifikansi) dari variabel bebas atau independen terhadap variabel terikat atau dependen (Gani dan Amalia, 2015). Pada analisis regresi model pertama, uji t dalam penelitian ini digunakan untuk mengetahui signifikansi pengaruh variabel independen (komunikasi, koordinasi maupun disiplin kerja) secara parsial dalam menerangkan variasi perubahan variabel dependen (kinerja pegawai). Tahapan pengujian hipotesis pertama, kedua dan hipotesis ketiga dalam penelitian ini adalah sebagai berikut:

Menentukan Hipotesis Statistika

Ho: $b_{1}$ atau $b_{2}$ atau $b_{3} \leq 0$

Secara parsial variabel independen (komunikasi, koordinasi maupun disiplin kerja) tidak mempunyai pengaruh yang positif signifikan terhadap variabel dependen (kinerja pegawai).

$\mathrm{H}_{\mathrm{a}}: \mathrm{b}_{1}$ atau $\mathrm{b}_{2}$ atau $\mathrm{b}_{3}>0$

Secara parsial variabel independen (komunikasi, koordinasi maupun disiplin kerja) mempunyai pengaruh yang positif signifikan terhadap variabel dependen (kinerja pegawai).

Menghitung nilai uji dengan rumus sebagai berikut (Gani dan Amalia, 2015):

$$
t \text { ? } \frac{b i}{S b i}
$$

Keterangan:

$\mathrm{t} \quad=$ thitung

bi = koefisian regresi variabel bebas ke-i

Sbi = standar error variabel bebas ke-i

Menentukan Level of Significance

Tingkat keyakinan menggunakan $95 \%$ atau level of significance $(\alpha)=0,05$ dan degree of freedom $(\mathrm{df})=(\mathrm{n}-\mathrm{k})$

Menentukan Kriteria Pengujian Satu Sisi (One Tailed)

Ho diterima jika nilai $t_{\text {hitung }} \leq t_{\text {tabel }}$ atau nilai signifikansi $<\alpha(0,05)$. Ho ditolak

jika nilai $t_{\text {hitung }}>\mathrm{t}_{\text {tabel }}$ atau nilai signifikansi $\geq \alpha(0,05)$.

Selanjutnya, pada analisis regresi model kedua, uji t digunakan untuk mengetahui signifikansi pengaruh variabel independen (komunikasi, koordinasi, disiplin kerja maupun kinerja pegawai) secara parsial dalam menerangkan variasi perubahan variabel dependen (efektivitas organisasi). Tahapan pengujian hipotesis keempat, kelima, keenam dan hipotesis ketujuh adalah sebagai berikut:

Menentukan Hipotesis Statistika

Ho: $b_{1}$ atau $b_{2}$ atau $b_{3}$ atau $b_{4} \leq 0$ 
Secara parsial variabel independen (komunikasi, koordinasi, disiplin kerja maupun kinerja pegawai) tidak mempunyai pengaruh yang positif signifikan terhadap variabel dependen (efektivitas organisasi).

$\mathrm{H}_{\mathrm{a}}: \mathrm{b}_{1}$ atau $\mathrm{b}_{2}$ atau $\mathrm{b}_{3}$ atau $\mathrm{b}_{4}>0$

Secara parsial variabel independen (komunikasi, koordinasi, disiplin kerja maupun kinerja pegawai) mempunyai pengaruh yang positif signifikan terhadap variabel dependen (efektivitas organisasi).

Menghitung nilai uji dengan rumus sebagai berikut (Gani dan Amalia, 2015):

$$
t \text { 回 }
$$

Sbi

Keterangan:

$\mathrm{t}=$ thitung

bi = koefisian regresi variabel bebas ke-i

$\mathrm{Sbi}=$ standar error variabel bebas ke-i

Menentukan Level of Significance

Tingkat keyakinan menggunakan $95 \%$ atau level of significance $(\alpha)=0,05$ dan degree of freedom $(\mathrm{df})=(\mathrm{n}-\mathrm{k})$

Menentukan Kriteria Pengujian Satu Sisi (One Tailed)

Ho diterima jika nilai $t_{\text {hitung }} \leq t_{\text {tabel }}$ atau nilai signifikansi $<\alpha(0,05)$. Ho

ditolak jika nilai $t_{\text {hitung }}>t_{\text {tabel }}$ atau nilai signifikansi $\geq \alpha(0,05)$.

\section{HASIL DAN PEMBAHASAN}

\section{Uji Validitas Kuesioner}

Berdasarkan output uji validitas kuesioner dapat diketahui nilai $\mathrm{r}_{\text {hitung }}$ korelasi product moment semua item pertanyaan dari variabel komunikasi $\left(\mathrm{X}_{1}\right)$, koordinasi $\left(\mathrm{X}_{2}\right)$, disiplin kerja $\left(\mathrm{X}_{3}\right)$, kinerja pegawai $\left(\mathrm{Y}_{1}\right)$ dan nilai $\mathrm{r}_{\text {hitung }}$ korelasi product moment semua item pertanyaan dari variabel efektivitas organisasi $\left(\mathrm{Y}_{2}\right)$ lebih besar dari nilai $\mathrm{r}_{\text {tabel }}$. Dengan demikian, maka seluruh item pertanyaan variabel tersebut dinyatakan valid dan dapat digunakan sebagai alat pengumpulan data.

\section{Uji Reliabilitas}

Berdasarkan output uji reliabilitas kuesioner dapat diketahui bahwa koefisien reliabilitas (cronbanch alpha) variabel komunikasi $\left(\mathrm{X}_{1}\right)$, koordinasi $\left(\mathrm{X}_{2}\right)$, disiplin kerja $\left(\mathrm{X}_{3}\right)$, kinerja pegawai $\left(\mathrm{Y}_{1}\right)$ maupun koefisien reliabilitas (cronbanch alpha) variabel efektivitas organisasi $\left(\mathrm{Y}_{2}\right)$ masing-masing lebih besar dari cut of value $(0,60)$ sehingga semua item pertanyaan untuk setiap variabel dalam penelitian ini dinyatakan reliabel dan dapat digunakan sebagai alat pengumpulan data.

\section{Uji Asumsi Klasik}

Uji Normalitas

Berdasarkan output uji asumsi klasik dapat diketahui nilai asymp. sig. (2-tailed) dari uji Kolmogorov-Smirnov Z adalah 0,790 lebih besar dari nilai ? $(0,05)$, sehingga dapat disimpulkan bahwa data berdistribusi normal.

Uji Multikolinearitas

Output uji multikolinearitas menunjukkan nilai Variance Inflation Factor (VIF) variabel komunikasi $\left(\mathrm{X}_{1}\right)$, koordinasi $\left(\mathrm{X}_{2}\right)$, disiplin kerja $\left(\mathrm{X}_{3}\right)$ maupun nilai VIF variabel kinerja pegawai $\left(\mathrm{Y}_{1}\right)$ masing- 
masing lebih kecil dari 10 sehingga dapat disimpulkan tidak terjadi multikolinearitas dalam model regresi.

Uji Heteroskedastisitas

Berdasarkan output uji heteroskedastisitas dapat diketahui nilai signifikansi uji $\mathrm{t}$ variabel komunikasi $\left(\mathrm{X}_{1}\right)$, koordinasi $\left(\mathrm{X}_{2}\right)$, disiplin kerja $\left(\mathrm{X}_{3}\right)$ maupun nilai signifikansi uji t variabel kinerja pegawai $\left(\mathrm{Y}_{1}\right)$ masing-masing lebih besar dari nilai o $(0,05)$ sehingga dapat disimpulkan tidak terdapat heteroskedastisitas dalam model regresi.

\section{Analisis Regresi Berganda Model Pertama}

Persamaan Regresi Berganda Model Pertama

Berdasarkan output analisis regresi berganda model pertama, selanjutnya dapat dibuat ringkasan hasil analisis seperti terlihat pada Tabel 2.

Tabel 2. Ringkasan Hasil Analisis Regresi Berganda Model Pertama

\begin{tabular}{|c|c|c|c|c|c|}
\hline & Variabel Bebas & Koefisien Regresi & $t_{\text {hitung }}$ & & $\begin{array}{c}\mathrm{t} \text { tabel } \\
\text { (one tailed) }\end{array}$ \\
\hline 1 & Komunikasi $\left(\mathrm{X}_{1}\right)$ & 0,400 & 4,142 & $>$ & 1,664 \\
\hline 2 & Koordinasi $\left(\mathrm{X}_{2}\right)$ & 0,358 & 3,747 & $>$ & 1,664 \\
\hline 3 & Disiplin Kerja $\left(\mathrm{X}_{3}\right)$ & 0,491 & 6,608 & $>$ & 1,664 \\
\hline \multicolumn{6}{|c|}{ Konstanta $=-1,256$} \\
\hline \multicolumn{6}{|c|}{ Koef. Determinasi $=0,517$} \\
\hline \multicolumn{6}{|c|}{ Adj. $R$ Square $\quad=0,499$} \\
\hline \multicolumn{6}{|c|}{ F Fitung $\quad=28,845$} \\
\hline
\end{tabular}

Berdasarkan data pada Tabel 2, selanjutnya dapat dibuat persamaan regresi berganda model pertama sebagai berikut:

$$
\mathrm{Y}_{1}=-1,256+0,400 \mathrm{X}_{1}+0,358 \mathrm{X}_{2}+0,491 \mathrm{X}_{3}
$$

Uji Kelayakan Model (Goodness of Fit)

Koefisien Determinasi

Ringkasan hasil analisis regresi berganda model pertama pada Tabel 2 di atas menunjukkan koefisien determinasi $\left(\mathrm{R}^{2}\right)$ sebesar 0,517 dan koefisien adjusted $R$ square adalah 0,499. Artinya sebesar 49,90 persen variasi perubahan variabel kinerja pegawai Satuan Polisi Pamong Praja (Satpol PP) Kabupaten Cilacap dapat dijelaskan oleh perubahan variabel komunikasi $\left(\mathrm{X}_{1}\right)$, koordinasi $\left(\mathrm{X}_{2}\right)$ dan variabel disiplin kerja $\left(\mathrm{X}_{3}\right)$, sedangkan 50,10 persen dapat dijelaskan oleh variabel-variabel lain yang tidak dimasukkan ke dalam model regresi.

Uji F

Ringkasan hasil analisis regresi berganda model pertama pada Tabel 2 juga menunjukkan nilai $F_{\text {hitung }}$ sebesar 28,845 lebih besar dari nilai $F_{\text {tabel }}$ dengan $\mathrm{df}=(\mathrm{k}-1)=(4-1)$ dan $(\mathrm{n}-\mathrm{k})=(85-4)$ sebesar 2,76. Hasil uji F tersebut menunjukkan bukti bahwa variabel komunikasi $\left(\mathrm{X}_{1}\right)$, koordinasi $\left(\mathrm{X}_{2}\right)$ dan disiplin kerja $\left(\mathrm{X}_{3}\right)$ secara bersama-sama (simultan) mempunyai pengaruh yang signifikan terhadap kinerja pegawai, atau dapat pula dinyatakan bahwa model regresi berganda model 
pertama yang terbentuk dinyatakan tepat atau cocok dengan data hasil penelitian (goodness of fit). Pengujian Hipotesis dengan Uji t

Pengujian signifikansi pengaruh komunikasi $\left(\mathrm{X}_{1}\right)$, koordinasi $\left(\mathrm{X}_{2}\right)$ maupun variabel disiplin kerja $\left(\mathrm{X}_{3}\right)$ terhadap kinerja pegawai $\left(\mathrm{Y}_{1}\right)$ secara parsial dilakukan menggunakan uji

t. Berdasarkan tingkat kesalahan ( $(2)=0,05$ dan degree of freedom $(n-k)=(85-4)=81$, maka dapat ditentukan nilai $t_{\text {tabel }}$ untuk pengujian satu sisi (one tailed) sebesar 1,664. Selanjutnya, dari ringkasan hasil analisis regresi berganda model pertama pada Tabel 2 dapat diketahui nilai $t_{\text {hitung }}$

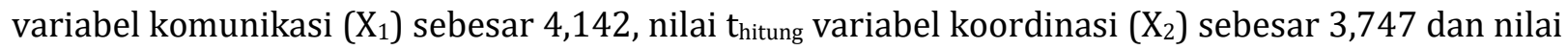

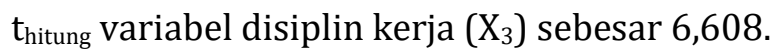

\section{Analisis Regresi Berganda Model Kedua}

Persamaan Regresi Berganda Model Kedua

Berdasarkan output analisis regresi berganda model kedua, selanjutnya dapat dibuat ringkasan hasil analisis seperti terlihat pada Tabel 3.

Tabel 3. Ringkasan Hasil Analisis Regresi Berganda Model Kedua

\begin{tabular}{|c|c|c|c|c|c|}
\hline & Variabel Bebas & Koefisien Regresi & $t_{\text {hitung }}$ & & $\begin{array}{c}\mathrm{t} \text { tabel } \\
\text { (one } \\
\text { tailed) }\end{array}$ \\
\hline 1 & Komunikasi $\left(\mathrm{X}_{1}\right)$ & 0,354 & 3,036 & $>$ & 1,664 \\
\hline 2 & Koordinasi $\left(\mathrm{X}_{2}\right)$ & 0,143 & 1,257 & $<$ & 1,664 \\
\hline 3 & Disiplin Kerja $\left(\mathrm{X}_{3}\right)$ & 0,310 & 3,060 & $>$ & 1,664 \\
\hline 4 & Kinerja Pegawai (Y) & 0,382 & 3,131 & $>$ & 1,664 \\
\hline \multicolumn{6}{|c|}{ Konstanta $\quad=-0,779$} \\
\hline \multicolumn{6}{|c|}{ Koef. Determinasi $=0,520$} \\
\hline \multicolumn{6}{|c|}{ Adj. $R$ Square $\quad=0,496$} \\
\hline & $F_{\text {hitung }} \quad=21,679$ & & & & \\
\hline
\end{tabular}

Berdasarkan data pada Tabel 3, selanjutnya dapat dibuat persamaan regresi berganda model kedua sebagai berikut:

$$
\mathrm{Y}_{2}=-0,779+0,354 \mathrm{X}_{1}+0,143 \mathrm{X}_{2}+0,310 \mathrm{X}_{3}+0,382 \mathrm{Y}_{1}
$$

Uji Kelayakan Model (Goodness of Fit)

Koefisien Determinasi

Ringkasan hasil analisis regresi berganda model kedua pada Tabel 3 di atas menunjukkan koefisien determinasi $\left(\mathrm{R}^{2}\right)$ sebesar 0,520 dan koefisien adjusted $R$ square adalah 0,496. Artinya sebesar 49,60 persen variasi perubahan variabel efektivitas organisasi Satuan Polisi Pamong Praja (Satpol PP) Kabupaten Cilacap dapat dijelaskan oleh perubahan variabel komunikasi $\left(\mathrm{X}_{1}\right)$, koordinasi $\left(\mathrm{X}_{2}\right)$, disiplin kerja $\left(\mathrm{X}_{3}\right)$ dan variabel kinerja pegawai $\left(\mathrm{Y}_{1}\right)$, sedangkan 50,40 persen dapat dijelaskan oleh variabel- variabel lain yang tidak dimasukkan ke dalam model regresi

Uji F

Ringkasan hasil analisis regresi berganda model kedua pada Tabel 3 juga menunjukkan nilai $F_{\text {hitung }}$ sebesar 21,679 lebih besar dari nilai $F_{\text {tabel }}$ dengan $d f=(k-1)$ dan $(n-k)$ sebesar 2,53. Hasil uji $F$ tersebut menunjukkan bukti bahwa variabel komunikasi $\left(\mathrm{X}_{1}\right)$, koordinasi $\left(\mathrm{X}_{2}\right)$, disiplin kerja $\left(\mathrm{X}_{3}\right)$ 
dan variabel kinerja pegawai $\left(\mathrm{Y}_{1}\right)$ secara bersama-sama (simultan) mempunyai pengaruh yang signifikan terhadap efektivitas organisasi, atau dapat pula dinyatakan bahwa model regresi berganda model kedua yang terbentuk dinyatakan tepat atau cocok dengan data hasil penelitian (goodness offit).

Pengujian Hipotesis dengan Uji t

Pengujian signifikansi pengaruh komunikasi $\left(\mathrm{X}_{1}\right)$, koordinasi $\left(\mathrm{X}_{2}\right)$, disiplin kerja $\left(\mathrm{X}_{3}\right)$ maupun variabel kinerja pegawai $\left(\mathrm{Y}_{1}\right)$ terhadap efektivitas organisasi $\left(\mathrm{Y}_{2}\right)$ secara parsial dilakukan menggunakan uji t. Berdasarkan tingkat kesalahan (?) = 0,05 dan degree offreedom ( $\mathrm{n}-\mathrm{k}$ ), dimana $\mathrm{n}=85$ dan $\mathrm{k}=5$, maka dapat ditentukan nilai $\mathrm{t}_{\text {tabel }}$ untuk pengujian satu sisi (one tailed) sebesar 1,664. Adapun dari ringkasan hasil analisis regresi berganda model kedua pada Tabel 3 dapat

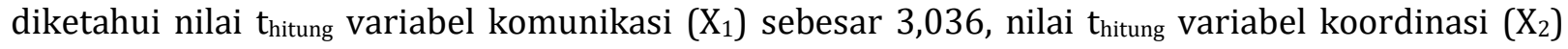

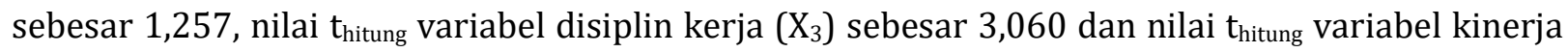
pegawai $\left(\mathrm{Y}_{1}\right)$ sebesar 3,131.

\section{Pengujian Hipotesis}

Ringkasan hasil analisis regresi berganda model pertama pada Tabel 2 di atas menunjukkan nilai

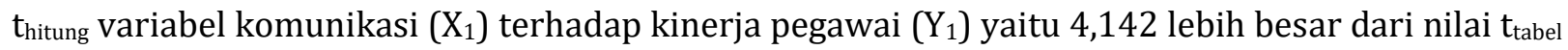
$(1,664)$. Dengan demikian, maka hipotesis pertama, diterima. Mengacu pada ringkasan hasil

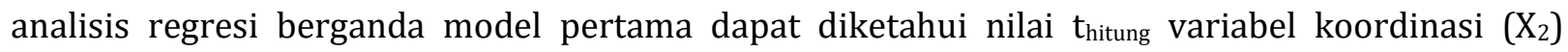
terhadap kinerja pegawai $\left(\mathrm{Y}_{1}\right)$ yaitu 3,747 lebih besar dari nilai $t_{\text {tabel }}(1,664)$. Dengan demikian, maka hipotesis kedua, diterima. Berdasarkan hasil analisis regresi berganda model pertama juga diperoleh nilai $t_{\text {hitung }}$ variabel disiplin kerja $\left(\mathrm{X}_{3}\right)$ terhadap kinerja pegawai $\left(\mathrm{Y}_{1}\right)$ yaitu 6,608 lebih besar dari nilai tabel $(1,664)$. Dengan demikian, maka hipotesis ketiga, diterima.

Ringkasan hasil analisis regresi berganda model kedua pada Tabel 3 di atas menunjukkan

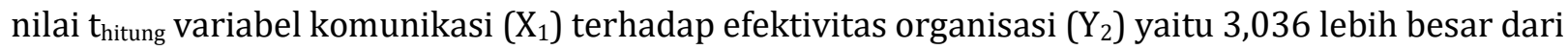
nilai $t_{\text {tabel }}(1,664)$. Dengan demikian, maka hipotesis keempat, diterima. Mengacu pada ringkasan

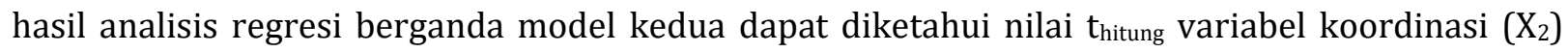
terhadap efektivitas organisasi $\left(\mathrm{Y}_{2}\right)$ yaitu 1,257 lebih kecil dari nilai $\mathrm{t}_{\text {tabel }}(1,664)$. Dengan demikian, maka hipotesis kelima, ditolak. Berdasarkan hasil analisis regresi berganda model kedua diperoleh

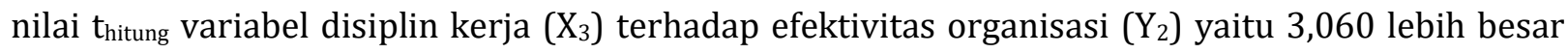
dari nilai ttabel $(1,664)$. Dengan demikian, maka hipotesis keenam, diterima. Selanjutnya, ringkasan hasil analisis berganda berganda model kedua pada Tabel 3 juga menunjukkan nilai $t_{\text {hitung variabel }}$ kinerja pegawai $\left(\mathrm{Y}_{1}\right)$ terhadap efektivitas organisasi $\left(\mathrm{Y}_{2}\right)$ yaitu 3,131 lebih besar dari nilai $t_{\text {tabel }}$ $(1,664)$. Dengan demikian, maka hipotesis ketujuh, diterima.

\section{Pembahasan Hasil Penelitian}

\section{Pengaruh Komunikasi Terhadap Kinerja Pegawai}

Hasil penelitian ini membuktikan bahwa komunikasi mempunyai pengaruh yang positif dan signifikan terhadap kinerja pegawai Satuan Polisi Pamong Praja (Satpol PP) Kabupaten Cilacap. Temuan dari hasil penelitian ini menunjukkan bukti bahwa semakin baik komunikasi, maka akan semakin baik pula tingkat pencapaian kinerja dari para pegawai Satuan Polisi Pamong Praja (Satpol PP) Kabupaten Cilacap. Secara teoritis, temuan penelitian ini sejalan dengan pendapat Kuswadi (2004) yang mengemukakan bahwa kinerja pegawai dipengaruhi oleh komunikasi. Secara empiris, hasil penelitian ini konsisten dengan temuan studi sebelumnya yang dilakukan oleh Ishtiaque dan Habib (2016); Marta dan Triwijayanti (2016) serta Rukmana et al., (2018) yang juga menemukan 
bukti bahwa komunikasi mempunyai pengaruh yang positif dan signifikan terhadap kinerja pegawai.

\section{Pengaruh Koordinasi Terhadap Kinerja Pegawai}

Hasil penelitian ini menemukan bukti bahwa koordinasi mempunyai pengaruh yang positif dan signifikan terhadap kinerja pegawai Satuan Polisi Pamong Praja (Satpol PP) Kabupaten Cilacap. Hubungan kausal tersebut membuktikan bahwa semakin baik koordinasi akan selalu diikuti dengan semakin tingginya tingkat pencapaian kinerja dari para pegawai Satuan Polisi Pamong Praja (Satpol PP) Kabupaten Cilacap. Secara empiris, hasil penelitian ini konsisten dengan temuan studi sebelumnya yang dilakukan oleh Octorano (2015); Fleury et al., (2017) serta Sariyanto (2018) dan Darmanto (2018) bahwa koordinasi berpengaruh positif dan signifikan terhadap kinerja pegawai.

\section{Pengaruh Disiplin Kerja Terhadap Kinerja Pegawai}

Selanjutnya, hasil penelitian ini juga membuktikan bahwa disiplin kerja mempunyai pengaruh yang positif dan signifikan terhadap kinerja pegawai Satuan Polisi Pamong Praja (Satpol PP) Kabupaten Cilacap. Hubungan kausal tersebut memberikan bukti bahwa semakin baik disiplin kerja dari para pegawai, maka akan semakin tinggi tingkat pencapaian kinerja dari para pegawai Satuan Polisi Pamong Praja (Satpol PP) Kabupaten Cilacap. Hasil penelitian ini sejalan dengan temuan studi sebelumnya yang dilakukan oleh Mangkunegara dan Waris (2015); Vionita, dkk., (2017) serta Hardiansyah (2017) bahwa disiplin kerja berpengaruh positif dan signifikan terhadap kinerja karyawan.

\section{Pengaruh Komunikasi Terhadap Efektivitas Organisasi}

Hasil penelitian ini membuktikan bahwa komunikasi mempunyai pengaruh yang positif dan signifikan terhadap efektivitas organisasi Satuan Polisi Pamong Praja (Satpol PP) Kabupaten Cilacap. Temuan penelitian ini menunjukkan bukti bahwa semakin baik komunikasi, maka akan semakin tinggi tingkat efektivitas organisasi Satuan Polisi Pamong Praja (Satpol PP) Kabupaten Cilacap. Secara teoritis, temuan penelitian ini sejalan dengan pendapat Menurut Muhammad (2011) yang mengemukakan bahwa dengan adanya komunikasi yang efektif, maka suatu organisasi dapat berjalan dengan baik dan berhasil dalam mencapai tujuannya. Secara empiris, hasil penelitian ini konsisten dengan temuan studi sebelumnya yang dilakukan oleh Shonubi dan Akintaro (2016); Widyastuti (2017) serta Ferdiansyah (2018) yang juga menemukan bukti bahwa komunikasi mempunyai pengaruh yang positif dan signifikan terhadap efektivitas organisasi.

\section{Pengaruh Koordinasi Terhadap Efektivitas Organisasi}

Hasil penelitian ini menunjukkan bahwa koordinasi mempunyai pengaruh yang positif namun tidak signifikan terhadap efektivitas organisasi Satuan Polisi Pamong Praja (Satpol PP) Kabupaten Cilacap. Hubungan kausal tersebut mengindikasikan bahwa semakin baik koordinasi tidak selalu diikuti dengan semakin tingginya tingkat efektivitas organisasi Satuan Polisi Pamong Praja (Satpol PP) Kabupaten Cilacap.

Berdasarkan temuan hubungan kausal antara koordinasi dengan efektivitas organisasi dalam penelitian ini, maka dapat dijelaskan bahwa meskipun organisasi Satuan Polisi Pamong Praja Kabupaten Cilacap telah menjalin kerjasama antarbadan, intansi maupun unit kerja dalam pelaksanaan tugas-tugas organisasi, namun proses kegiatan dalam rangka pencapaian tujuan organisasi belum dapat berjalan secara efektif sesuai dengan yang diharapkan. Kondisi demikian dapat terjadi karena dalam menjalin kerjasama antarbadan, intansi maupun unit kerja secara horizontal seringkali dihadapkan pada adanya tumpang tindih tugas dan wewenang serta adanya 
perbedaan visi dan misi organisasi sehingga dalam pelaksanaan tugas di lapangan setiap badan, instansi dan unit kerja lebih berorientasi pada tujuannya masing-masing. Di samping itu, dalam pelaksanaan tugas di lapangan juga terkadang tidak berjalan sesuai dengan yang direncanakan karena adanya perubahan situasi dan kondisi dari masing-masing badan, instansi dan unit kerja yang sebelumnya tidak mudah untuk diprediksi. Hal-hal tersebut menjadikan koordinasi yang dilaksanakan oleh organisasi Satuan Polisi Pamong Praja Kabupaten Cilacap dengan pihak-pihak lain belum mampu meningkatkan efektivitas organisasi secara signifikan.

Secara empiris, hasil penelitian ini berbeda dengan temuan studi yang dilakukan oleh Enadarlita dan Asvio (2019) bahwa koordinasi mempunyai pengaruh yang positif dan signifikan terhadap efektivitas organisasi. Di sisi lain, hasil penelitian ini konsisten dengan temuan studi sebelumnya yang dilakukan oleh Ainiyah, dkk., (2017) bahwa koordinasi tidak berpengaruh signifikan terhadap efektivitas organisasi.

\section{Pengaruh Disiplin Kerja Terhadap Efektivitas Organisasi}

Penelitian ini membuktikan bahwa disiplin kerja mempunyai pengaruh yang positif dan signifikan terhadap efektivitas organisasi Satuan Polisi Pamong Praja (Satpol PP) Kabupaten Cilacap. Hubungan kausal tersebut memberikan bukti bahwa semakin baik disiplin kerja dari para pegawai akan selalu diikuti dengan semakin tingginya tingkat efektivitas organisasi Satuan Polisi Pamong Praja (Satpol PP) Kabupaten Cilacap. Hasil penelitian ini sejalan dengan temuan studi sebelumnya yang dilakukan oleh Idris dan Alegbeleye (2015) bahwa terdapat hubungan yang positif dan signifikan antara disiplin kerja dengan efektivitas organisasi. Selanjutnya, temuan dari penelitian ini juga konsisten dengan hasil studi yang dilakukan oleh Purnomo (2006) serta Nduka et al., (2019) yang juga menemukan bukti bahwa disiplin kerja berpengaruh positif dan signifikan dengan efektivitas organisasi.

\section{Pengaruh Kinerja Pegawai Terhadap Efektivitas Organisasi}

Hasil penelitian ini menemukan bukti bahwa kinerja pegawai mempunyai pengaruh yang positif dan signifikan terhadap efektivitas organisasi Satuan Polisi Pamong Praja (Satpol PP) Kabupaten Cilacap. Hubungan kausal tersebut menunjukkan bukti bahwa semakin baik kinerja pegawai akan selalu diikuti dengan semakin tingginya tingkat efektivitas organisasi Satuan Polisi Pamong Praja (Satpol PP) Kabupaten Cilacap. Secara teoritis, temuan penelitian ini sejalan dengan pendapat Jassim dan Jaber (2007) bahwa penilaian kinerja pegawai memiliki peran penting dalam mengevaluasi perilaku anggota organisasi dalam mencapai tujuan organisasi. Secara empiris, hasil penelitian ini konsisten dengan temuan studi sebelumnya yang dilakukan oleh Tahsildari dan Shahnaei (2015); Fernanda (2015) dan Zulkarnain (2012) yang juga membuktikan bahwa kinerja pegawai mempunyai pengaruh yang positif dan signifikan terhadap efektivitas organisasi.

\section{SIMPULAN DAN IMPLIKASI}

\section{Simpulan}

Komunikasi mempunyai pengaruh yang positif dan signifikan terhadap kinerja pegawai Satuan Polisi Pamong Praja (Satpol PP) Kabupaten Cilacap. Koordinasi mempunyai pengaruh yang positif dan signifikan terhadap kinerja pegawai Satuan Polisi Pamong Praja (Satpol PP) Kabupaten Cilacap. Disiplin kerja mempunyai pengaruh yang positif dan signifikan terhadap kinerja pegawai Satuan Polisi Pamong Praja (Satpol PP) Kabupaten Cilacap. Komunikasi mempunyai pengaruh yang positif 
dan signifikan terhadap efektivitas organisasi Satuan Polisi Pamong Praja (Satpol PP) Kabupaten Cilacap. Koordinasi mempunyai pengaruh yang positif namun tidak signifikan terhadap efektivitas organisasi Satuan Polisi Pamong Praja (Satpol PP) Kabupaten Cilacap.

Disiplin kerja mempunyai pengaruh yang positif dan signifikan terhadap efektivitas organisasi Satuan Polisi Pamong Praja (Satpol PP) Kabupaten Cilacap. Kinerja pegawai mempunyai pengaruh yang positif dan signifikan terhadap efektivitas organisasi Satuan Polisi Pamong Praja (Satpol PP) Kabupaten Cilacap.

\section{Implikasi}

Sebagai upaya untuk terus meningkatkan kinerja pegawai dan efektivitas organisasi, pihak Satuan Polisi Pamong Praja (Satpol PP) Kabupaten Cilacap perlu memprioritaskan kebijakan yang terkait dengan komunikasi dan disiplin kerja. Cara yang dapat dilakukan diantaranya adalah dengan menerapkan sistem komunikasi kerja yang efektif sesuai dengan etika komunkasi organisasi yaitu adanya keterbukaan, empati, dukungan dan kesetaraan, dimana hal tersebut bertujuan untuk menciptakan suasana pertukaran informasi yang lebih santai serta komunikasi menjadi terasa hangat sehingga gagasan, pikiran dan ide dari satu orang kepada orang lain di dalam organisasi Satuan Polisi Pamong Praja (Satpol PP) Kabupaten Cilacap dapat diterima dengan baik. Pihak Satuan Polisi Pamong Praja (Satpol PP) Kabupaten Cilacap juga perlu untuk terus meningkatkan kesadaran para pegawai mengenai pentingnya sikap saling menghormati dan saling menghargai antar sesama pegawai, meningkatkan kepatuhan dan ketaatan pegawai terhadap peraturanperaturan yang berlaku terkait dengan pelaksanaan pekerjaan dengan cara memberikan sanksi secara tegas dan adil terhadap pelanggaran, kesalahan maupun kelalaian kerja yang dilakukan pegawai, membagikan peraturan organisasi secara tertulis kepada masing-masing pegawai sesuai dengan bidang tugas yang menjadi tanggung jawabnya, memasang tata tertib dan prosedur kerja di kantor maupun tempat kerja dari masing-masing pegawai serta memberikan penghargaan (reward) kepada pegawai yang mampu memegang teguh dan melaksanakan nilai-nilai disiplin kerja dalam organisasi Satpol PP Kabupaten Cilacap.

\section{DAFTAR PUSTAKA}

Afandi, P., (2016). Concept \& Indicator Human Resources Management for Management Research, Deepublish, Yogyakarta.

Darmanto, Rochmad Fadjar, (2018). Pengaruh Budaya, Disiplin dan Koordinasi Terhadap Kinerja Karyawan PT. Kereta Api Indonesia (Persero) DAOP 1 Jakarta, Jurnal Pengembangan Wiraswasta, Vol. 20, No. 02, Hal: 79-94. 
Fefni, Kaldian, (2017). Efektivitas Komunikasi Organisasi, Kepuasan Komunikasi dan Kinerja Tenaga Keperawatan (Studi pada RSUD Dr. Muhammad Zein Painan), Masters Thesis, Universitas Andalas.

Fleury, Marie-Josée, Guy Grenier, Jean-Marie Bamvita dan François Chiocchio, (2017). Variables Associated with Work Performance in Multidisciplinary Mental Health Teams, Journal of SAGE Open Medicine, Vol. 5, No, 1, Hal: 1-12.

Gani, Irwan dan Siti Amalia, (2015). Alat Analisis Data: Aplikasi Statistik untuk Penelitian Bidang Ekonomi dan Sosial, Penerbit ANDI, Yogyakarta.

Handoko, T., Hani, (2001). Manajemen Personalia dan Sumber Daya Manusia, Liberty, Yogyakarta.

Hardiansyah, Rian Oztary, (2017). Pengaruh Etos Kerja dan Disiplin Kerja Terhadap Kinerja Pegawai (Studi pada Pegawai Dinas Pekerjaan Umum Kota Magelang), Skripsi, UNY, Yogyakarta.

Hasibuan, Malayu S.P., (2010). Manajemen Sumber Daya Manusia, Penerbit Bumi Aksara, Jakarta.

Idris, Sule D., dan G. Ilesanmi Alegbeleye, (2015). Discipline and Organization Effectiveness: A Study of Nigeria Customs Service, Review of Public Administration and Management, Vol. 4, No. 8, ISSN: 2315-7844.

Ishtiaque, F., dan Laila Habib, (2016). Impact of Internal Communication in Organizational Development, International Journal of Trend in Research and Development, Vol. 3, No. 5, ISSN: 2394-9333.

Kuswadi, (2004). Mengukur Kepuasan Kerja Karyawan, PT. Elex Media Komputindo Gramedia, Jakarta.

Lovihan, Lisa J., (2018). Analisis Koordinasi dan Pengawasan serta Hubungannya dengan Kinerja Karyawan PT. Berkat Nikita Waya Lansot di Minahasa Utara, Jurnal EMBA, Vol. 6, No. 4, Hal: 2378-2387.

Mahmudi, (2010). Manajemen Kinerja Sektor Publik, UPP STIM YKPN, Yogyakarta. Mangkunegara, A,P., 2009. Manajemen Sumber Daya Manusia Perusahaan, PT. Remaja

Rosdakarya, Bandung.

Mangkunegara, A.P., dan Abdul Waris, (2015). Effect of Training, Competence and Discipline on Employee Performance in Company, Procedia - Social and Behavioral Sciences, Vol. 211, Hal: 1240 - 1251.

Moekijat, (2010). Manajemen Sumber Daya Manusia, CV. Mandar Maju, Bandung.

Nawawi, H., (2006). Manajemen Sumber Daya Manusia, Gadjah Mada University Press, Yogyakarta.

Osifo, Omoregie Charles, (2013). The Effects of Coordination on Organizational Performance: An Intra and Inter Perspective, Asian Journal of Business and Management, Vol. 01, Issue 04, ISSN: 2321 - 2803.

Peraturan Daerah Kabupaten Cilacap Nomor 9 Tahun 2016 Tentang Pembentukan Dan Susunan Perangkat Daerah Kabupaten Cilacap.

Peraturan Pemerintah No. 6 Tahun 2010 Tentang Satuan Polisi Pamong Praja Prawirosentono, Suryadi, 2008. Kebijakan Kinerja Karyawan, BPFE, Yogyakarta. Robbins, S.P., 2010. Organizational Behaviour, Prentice Hall, Inc., New Jersey.

Robbins, Stephen P., dan Timothy A. Judge, (2015). Perilaku Organisasi, Salemba Empat, Jakarta.

Roziqin, Muhammad Zainur, (2010). Kepuasan Kerja, AvePress, Malang.

Rukmana, H.D., Sopiah dan Elfia Nora, (2018). The Impact of Organization Communication on Employee Performance Through Employee's Work Motivation at PT. Putri Panda Unit II Tulungagung, East Jawa, Indonesia, The First International Research Conference on Economics and Business, KnE Social Sciences, Hal: 211-227.

Ruky, Achmad S., (2006). Sistem Manajemen Kinerja, PT. Gramedia. Pustaka Utama, Jakarta. Sastrohadiwiryo, B. Siswanto, 2005. Manajemen Tenaga Kerja Indonesia: Pendekatan 
Administratif dan Operasional, Bumi Aksara, Jakarta.

Septiani, Ade Irma, (2018). Pengaruh Komunikasi dan Koordinasi Terhadap Kinerja Karyawan pada PT. Pelabuhan Indonesia 1 (Persero) Medan, Skripsi, Universitas Muhammadiyah Sumatera Utara, Medan.

Shonubi, A.O., dan A.A. Akintaro, (2016). The Impact of Effective Communication on Organizational Performance, The International Journal of Social Sciences and Humanities Invention, Vol. 3, Issue 3, Hal: 1904-1914.

Siagian, Sondang P., (2014). Manajemen Sumber Daya Manusia, Bumi Aksara, Jakarta. Simamora, Henry, 2010. Manajemen Sumber Daya Manusia, STIE YKPN, Yogyakarta.

Siyoto, Sandu dan Ali Sodik, (2015). Dasar Metodologi Penelitian, Literasi Media Publishing, Yogyakarta.

Solihin, Ismail, (2009). Pengantar Manajemen, Erlangga, Jakarta Steers, Richard M., 1977. Efektivitas Organisasi, Erlangga, Jakarta.

Stoner, James A.F., (1982). Management, Prentice/Hall International, Inc., Englewood Cliffs, New York.

Sugiyono, (2009). Metode Penelitian Kuantitatif, Kualitatif dan R\&D, Alfabeta, Bandung. Suliyanto, (2006). Metode Riset Bisnis, Andi, Yogyakarta. (2011). Ekonometrika Terapan: Teori dan Aplikasi dengan SPSS, Andi, Yogyakarta. Sutrisno,

Suzanto, Boy dan Dewi Fitriasari, (2014). Pengaruh Motivasi Kerja, Disiplin Kerja dan Koordinasi Terhadap Kinerja Pegawai (Suatu Studi pada Cabang Pelayanan Dinas Pendapatan Daerah Provinsi Wilayah Kota Bandung III Soekarno Hatta), Jurnal Ekonomi, Bisnis \& Entrepreneurship, Vol. 8, No. 2, Oktober 2014, Hal. 123-136.

Tahsildari, Amin dan Shila Shahnaei, (2015). Enhancing Organizational Effectiveness by Performance Appraisal, Training, Employee Participation, and Job Definition, European Journal of Business and Management, Vol. 7, No. 12, ISSN: 2222-2839.

Tangkilisan, Hesel Nogi S., (2005). Strategi Keunggulan Pelayanan Publik: Manajemen Sumber Daya Manusia Birokrasi Publik (Konsep-Teori \& Praktek), Lukman Offset, Yogyakarta.

Umar, Husein, (2002). Metode Riset Bisnis, PT. Gramedia Pustaka Utama, Jakarta.

(2012). Metode Riset Komunikasi Organisasi, PT. Gramedia Pustaka Utama, Jakarta.

Undang-Undang Nomor 23 Tahun 2014 Tentang Pemerintahan Daerah

Vionita, Gustria, Mimpin Sitepu dan Fery Panjaitan, (2017). Analisis Pengaruh Disiplin Kerja, Loyalitas dan Pengalaman Kerja Terhadap Kinerja Kerja Karyawan pada PT. Bank Tabungan Negara (Persero), Tbk Cabang Pangkalpinang, Jurnal Ilmiah Progresif Manajemen Bisnis (JIPMB), Vol. 18, No. 2, November 2017 ISSN 2354-5682.

Zainal, V. Rivai, Mansyur Ramli, Thoby Mutis dan Willy Arafah, (2015). Manajemen Sumber Daya Manusia untuk Perusahaan: Dari Teori Ke Praktik, Rajawali Pers, Jakarta. 